\title{
Aerococcus-like organisms isolated from human infections
}

\author{
G. COLMAN \\ From the Department of Bacteriology, Wright-Fleming Institute, St. Mary's Hospital \\ Medical School, London
}

SYNOPSIS Ten strains of Gram-positive cocci isolated from patients with endocarditis and other infections, though resembling enterococci, proved to belong to the Aerococcus-Pediococcus-Gaffkya group of bacteria.

During a study of non-haemolytic streptococci, some strains originally isolated from patients with endocarditis or urinary tract infections were found to be similar in many ways to enterococci but were found to differ from enterococci in being unable to survive exposure to a temperature of $60^{\circ} \mathrm{C}$. for 30 minutes and in being unable to split arginine. And when the range of tests employed was extended, it became clear that these cocci were not streptococci but belonged to what might loosely be called the Aerococcus-Pediococcus-Gaffkya group of bacteria. There are reports of the isolation of similar bacteria from patients (Guthof, 1960; de Moor, 1964) but since their principal recognized reservoirs are air Received for publication 12 December 1966.
(Williams, Hirch, and Cowan, 1953), breweries (Nakagawa and Kitahara, 1959), meat-curing brines (Deibel and Niven Jr., 1960), the dregs in medicine bottles (Clausen, 1964), and lobsters (Wood, 1965) they are not commonly distinguished by medical bacteriologists. They are much more sensitive to antibiotics than the enterococci with which they are confused, so that the distinction may well be a useful one to make.

MATERIALS AND METHODS

STRAINS The strains studied are listed in Table I. Eight strains from patients are brought together to form division 1 and of these strains, four were isolated from blood cultures of patients with endocarditis, three from

TABLE I

SOURCES OF BACTERIA

Designation in Table II Designation when Received or Designation Given Source

\begin{tabular}{|c|c|c|c|}
\hline $\begin{array}{l}\text { Division } 1 \\
\text { (8 strains) }\end{array}$ & $\begin{array}{l}\text { FW297 } \\
\text { BU125 } \\
\text { BU150a } \\
\text { BU183 } \\
\text { FW77 } \\
\text { FW80 } \\
\text { Kiel 6186 } \\
\text { FW82 }\end{array}$ & $\begin{array}{l}\text { Endocarditis } \\
\text { Endocarditis } \\
\text { Endocarditis } \\
\text { Endocarditis } \\
\text { Urinary tract infection } \\
\text { Urinary tract infection } \\
\text { Urinary tract infection } \\
\text { Empyema }\end{array}$ & $\begin{array}{l}\text { (W.F.I.) } \\
\text { (Bucharest) } \\
\text { (Bucharest) } \\
\text { (Bucharest) } \\
\text { (W.F.I.) } \\
\text { (W.F.I.) } \\
\text { (Kiel) } \\
\text { (W.F.I.) }\end{array}$ \\
\hline $\begin{array}{l}\text { Division } 2 \\
\text { Division } 3\end{array}$ & $\begin{array}{l}\text { FW52 } \\
\text { FW125 }\end{array}$ & $\begin{array}{l}\text { Infected wound } \\
\text { Mouth }\end{array}$ & $\begin{array}{l}\text { (W.F.I.) } \\
\text { (W.F.I.) }\end{array}$ \\
\hline $\begin{array}{l}\text { Division } 4 \\
\quad \text { (6 strains) } \\
\text { Division } 5 \\
\text { (7 strains) }\end{array}$ & $\begin{array}{l}\text { Aerococcus viridans } 8251,7777,7600,7592 \\
\text { Pediococcus homari } 10331 \\
P \text {. urinae-equi } 1636 \\
P \text {. cerevisiae } 8066 \\
P \text {. acidilactici } 8018 \\
P \text {. pentosaceus } 7837,8106 \\
P \text {. cerevisiae NZ-R2 } \\
P \text {. parvulus } \text { F98 } \\
P \text {. pentosaceus } \text { Mees' strain }\end{array}$ & $\begin{array}{l}\mathbf{N} . \\
\mathbf{N} . \\
\mathbf{N} . \\
\mathbf{N} . \\
\mathbf{N} . \\
\mathbf{N} . \\
\mathbf{Q} . \\
\mathbf{Q} . \\
\mathbf{D e}\end{array}$ & \\
\hline $\begin{array}{l}\text { Division } 6 \\
\text { (15 strains) }\end{array}$ & \multicolumn{3}{|c|}{ Strains of Streptococcus faecalis, results from a survey to be published elsewhere } \\
\hline
\end{tabular}


patients with urinary tract infections, and one from a patient with empyema. Single strains, also isolated from humans, make up divisions 2 and 3.

For comparison, three groups of strains are included. Division 4 contains six strains from culture collections that are clearly alike and closely resemble the strains in division 1. Included here are four strains of Aerococcus viridans, one strain of Pediococcus homari (Gaffkya homari), and one strain of $P$. urinae-equi. This last strain has identical reactions with Mees' (1934) strain of $P$. urinae-equi, received directly from Professor T. O. Wikén of the Technical University, Delft, and the results with the latter strain are not included as it is possible that two subcultures of a single strain have been studied. The strains in division 5 are, like the strains in division 4 , from culture collections. Bacteria such as these are found in foodstuffs, for example New Zealand cheddar cheese (Dacre, 1958), and the fact that some of these strains contain an antigen reacting with Lancefield group D antiserum (Coster and White, 1964) makes them of interest even if they are not of clinical importance. Lastly, the results obtained with 15 strains of Streptococcus faecalis have been included and these make up division 6 .

TESTS Most of the tests summarized in Table II were carried out by conventional methods. However, the ability to hydrolyse arginine was tested in the medium of Niven Jr., Smiley, and Sherman (1942), but the culture fluid was diluted to 1 in 10 in a test tube with water before Nessler's reagent was added. The production of acid from glucose under anaerobic conditions was tested in the manner advocated for the study of micrococci and staphylococci (Recommendations, 1965). The bacterial cell walls were isolated and examined by the methods described by Colman and Williams (1965), except that disintegration of the cells with glass beads took 15 minutes instead of the 10 minutes necessary for streptococci.

Oxoid Multodisks (code number 566E) were used for the disc sensitivity tests and the antibiotics tested were tetracycline $(10 \mu \mathrm{g}$.), chloramphenicol (10 $\mu \mathrm{g}$.), erythromycin $(10 \mu \mathrm{g}$.), neomycin (10 $\mu \mathrm{g}$.), novobiocin $(5 \mu \mathrm{g}$.), cloxacillin $(5 \mu \mathrm{g}$.$) , penicillin (0.9 \mu \mathrm{g}$.), and streptomycin $(10 \mu \mathrm{g}$.$) . The tests were made on horse blood agar plates.$ The minimal inhibitory concentrations (M.I.C.) of benzylpenicillin were determined by diluting the antibiotic in infusion broth and then seeding the culture tubes with $0.02 \mathrm{ml}$. of $10^{-6}$ dilutions of overnight cultures of the test strains.

\section{RESULTS}

PHYSIOLOGICAL AND BIOCHEMICAL TESTS In outline, the bacteria allocated to divisions 1 and 2 of Table II are Gram-positive cocci that grow on agar containing $40 \%$ bile, do not give a strong catalase reaction, and do not form chains in glucose broth. These findings could lead to the conclusion that they are enterococci. However, none fulfils Sherman's (1937) criteria for enterococci, namely, growth at $45^{\circ} \mathrm{C}$., growth in the presence of $6.5 \% \mathrm{NaCl}$, the production of ammonia from arginine, and survival after heating to $60^{\circ} \mathrm{C}$. for

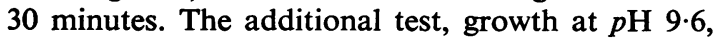

was not done. Moreover, the failure to produce acid from glucose under anaerobic conditions and the failure to grow in the depths of shake cultures distinguish these strains from streptococci.

The eight strains isolated from patients and placed in division 1 are very like the culture collection strains whose attributes are listed in division 4 of Table II and they might therefore properly be classed as Aerococci.

The single strain (FW52) in division 2 is closer to the enterococci than any of the strains in divisions 1 and 4 because it splits arginine and survives $60^{\circ} \mathrm{C}$. for 30 minutes. The single strain in division 3 (FW125) is unlike any other strain in this collection in its failure to grow on bile agar or in media containing even moderate amounts of salt.

The 15 enterococci (division 6) can be distinguished from the aerococci and similar strains by Lancefield grouping, the ability of the enterococci to grow on media of moderately acid reaction such as tomato juice agar (Oxoid), their tolerance of anaerobic conditions, and ability to grow in broth maintained at $45^{\circ} \mathrm{C}$. In Table II the two-day readings of the sugar fermentation tests have been given as these emphasize differences between enterococci and the other cocci; the enterococci show fewer delayed reactions.

The strains brought together with the strain $P$. pentosaceus of Mees (division 5) differ from the other bacteria described here by the ability to grow on acetate agar at pH 5.4 (Whittenbury, 1965).

The residues, detected in hydrolysates of whole cell walls, that might be of differential value are listed in Table II. All strains yielded muramic acid and glucosamine and the amino acids lysine, alanine, and glutamic acid; none of these residues is therefore listed in Table II. The amino acids leucine (or isoleucine) and valine, found frequently in small amounts in hydrolysates of cell walls of streptococci, were not found in hydrolysates of cell walls of strains from the other genera.

SEROLOGY Crude acid extracts of all strains were tested for precipitation against Lancefield grouping sera of the established or proposed groups $A$ to $T$. Acid extracts partially purified by alcohol precipitation (Shattock, 1949) were additionally tested against sera of groups $D, N$, and $Q$. The only reactions detected were between group $D$ sera and extracts of enterococci and strains related to $P$. pentosaceus.

Heat-killed subcultures of seven strains were injected intravenously into rabbits and antisera against two of these strains (FW82 and FW297) yielded a precipitate with crude acid extracts of six of the nine strains of aerococci in divisions 1 and 2, including the strain FW52. None of these sera yielded a precipitate 
TABLE II

THE PHYSIOLOGICAL AND BIOCHEMICAL REACTIONS OF STRAINS Division ${ }^{1}$

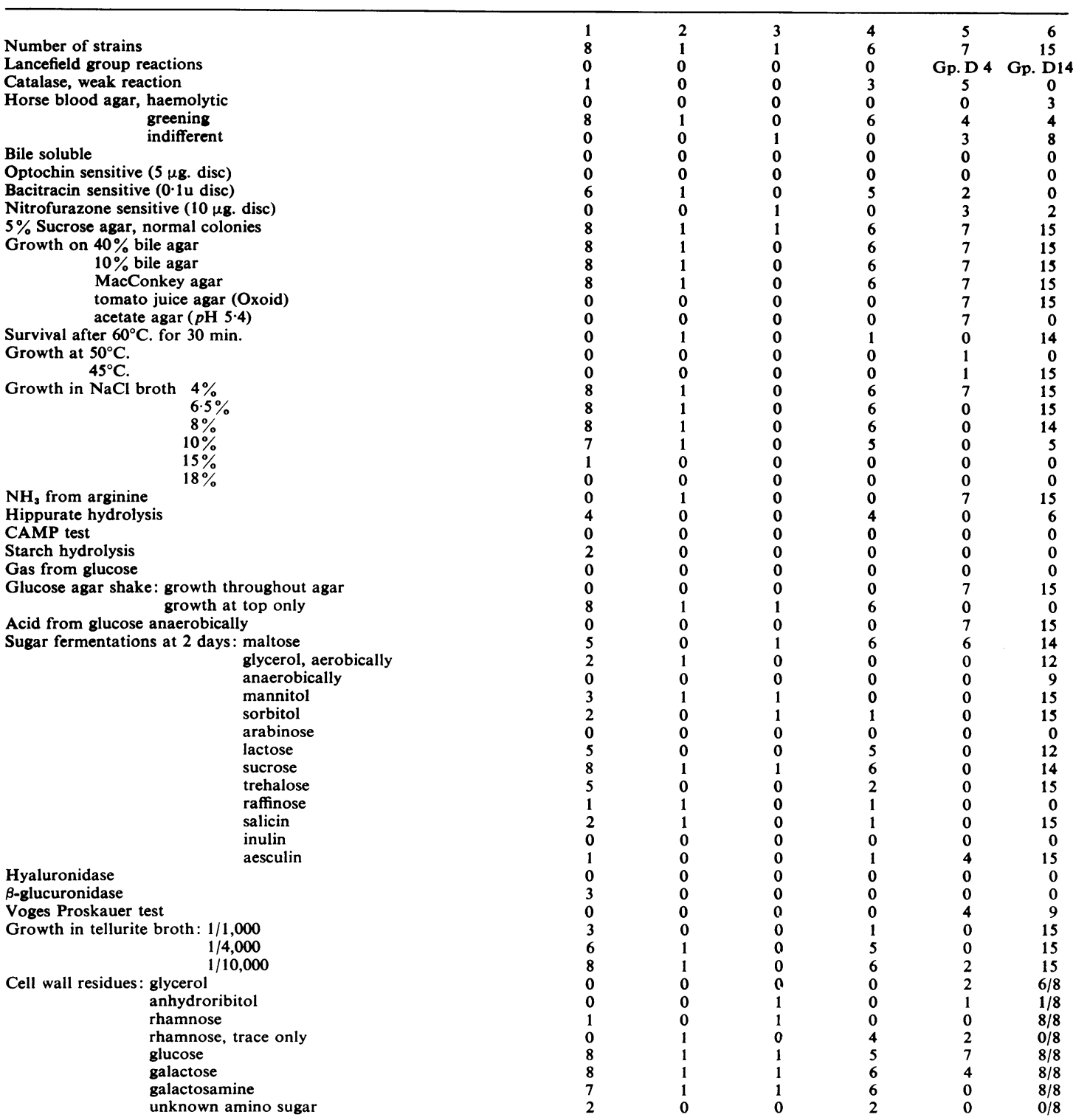

${ }^{1}$ Divisions 1, 2 and 3, strains from humans. Division 4, Aerococcus viridans and related strains. Division 5 , Pediococcus pentosaceus and related strains. Division 6, Streptococcus faecalis and its varieties.

with acid extracts of streptococci of the groups A to $\mathrm{T}$, nor with the pediococci listed in division 5 in Table I.

ANTIBIOTIC SENSITIVITIES The 10 strains in divisions
1,2 , and 3, which were isolated from humans, have been tested for sensitivity to eight antibiotics (Table III). Seven of the total of 10 strains were sensitive to $\varrho$ all antibiotics used. For comparison eight strains of $\bar{\gamma}$ $S$. faecalis var. faecalis recently isolated from the 
TABLE III

SENSITIVITIES TO ANTIBIOTICS

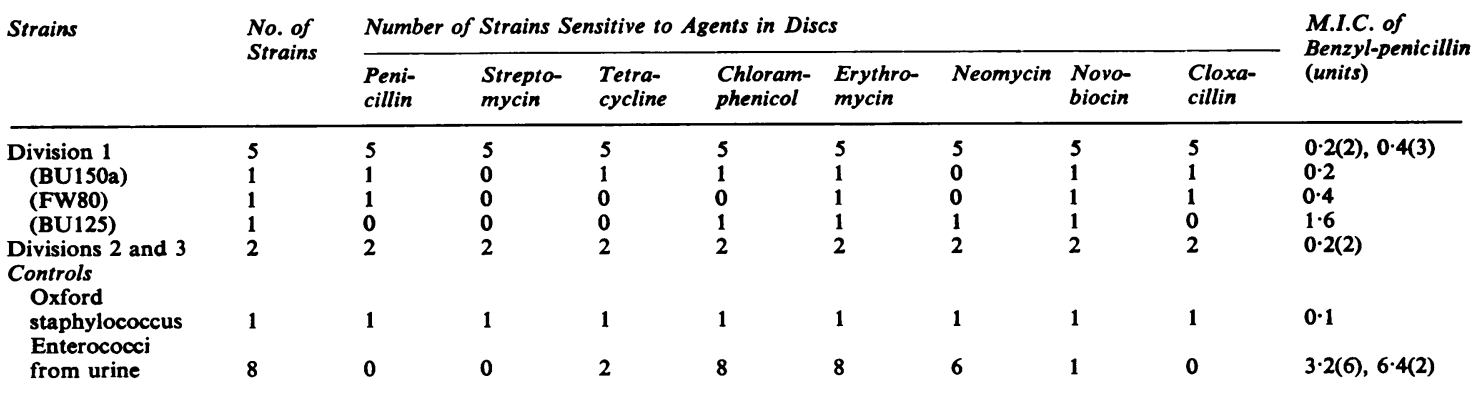

urine of other patients (and not included in Tables I and II) were similarly tested and found to be more resistant to antibiotics.

\section{DISCUSSION}

The bacteria described here, which were isolated from cultures of urine or blood, are very similar to the strains from culture collections called Aerococcus viridans, Pediococcus homari, or Pediococcus urinaeequi. The isolation of bacteria such as these from patients has been reported by Guthof (1960) and also by de Moor (1964), but little attention has been paid to these reports. The nomenclature and classification of this group of organisms is very confused, but the similarity of $A$. viridans, $P$. homari and $P$. urinae-equi has been noted by Deibel and Niven (1960) and by Whittenbury (1965).

Nakagawa and Kitahara (1959) would divide the genus Pediococcus into three groups. One division contains $P$. urinae-equi, and Nakagawa and Kitahara call it the acid-sensitive group. This group corresponds to the strains included in divisions 1 and 4 of this paper. Their second group contains Mees' strain of $\boldsymbol{P}$. pentosaceus and the attributes of their strains are comparable to those listed in division 5 of this paper. The final division of Nakagawa and Kitahara contains strains that can cause 'sick' beer. The results with a few strains, obtained from culture collections, have not been included as the strains studied grew neither at $37^{\circ} \mathrm{C}$. nor on blood agar plates.

The failure of which strains to produce acid from glucose under anaerobic conditions could be made the basis for their classification in the genus Micrococcus, but none gives a strong catalase reaction. The nomenclature of these strains is made even more complex by the statements of Kocur and Martinec (1965) who would abolish the genus Gaffkya and place some of its members in the genus Staphylococcus and others in the genus Pediococcus.
These bacteria are of importance to dairy, food, and brewing bacteriologists. It would seem safer to await further researches on the classification and nomenclature of the pediococci and related bacteria before advocating a Latin binomial for the strains that are isolated from patients. In the meantime the trivial name aerococcus would seem appropriate.

\section{CONCLUSIONS}

The bacteria described here, which had been isolated from lesions in man, are very similar to strains of the Aerococcus-Pediococcus-Gaffkya group of bacteria isolated from other environments such as lobsters or the urine of horses. It is of interest that they can act as opportunist pathogens in man. In a busy laboratory they could be confused with enterococci but as they differ in antibiotic sensitivities it may be useful to distinguish them.

This investigation is supported by the Medical Research Council. Workers in the laboratories named in Table I generously sent strains for examination.

\section{REFERENCES}

Clausen, O. G. (1964). J. gen. Microbiol., 35, 1.

Colman, G., and Williams, R. E. O. (1965). Ibid., 41, 375.

Coster, E., and White, H. R. (1964). Ibid., 37, 15.

Dacre, J. C. (1958). J. Dairy Res., 25, 409.

Deibel, R. H., and Niven, C. F., Jr. (1960). J. Bact., 79, 175.

de Moor C. E. (1964). Versl. Volksgezondh., 238.

Guthof, O. (1960). Z. Hyg. Infekt.-Kr., 146, 425.

Kocur, M., and Martinec, T. (1965). Int. Bull. bact. Nomencl., 15, 177. Mees, R. H. (1934). Thesis, Delft.

Nakagawa, A., and Kitahara, K. (1959). J. gen. appl. Microbiol, 5, 95. Niven, C. F., Jr., Smiley, K. L., and Sherman, J. M. (1942). J. Bact., 43, 651 .

Recommendations; Subcommittee on Taxonomy of Staphylococci and Micrococci. (1965). Int. Bull. bact. Nomencl., 15, 109.

Shattock, P. M. F. (1949). J. gen. Microbiol., 3, 80.

Sherman, J. M. (1937). Bact. Rev., 1, 3.

Whittenbury, R. (1965). J. gen. Microbiol., 40, 97.

Williams, R. E. O., Hirch, A., and Cowan, S. T. (1953). Ibid., $8,475$.

Wood, P. C. (1965). J. gen. Microbiol., 41, xxviii. 